\title{
2. GLOBAL SEA-LEVEL CHANGE AND THE NEW JERSEY MARGIN ${ }^{1}$
}

\author{
K.G. Miller ${ }^{2,3}$ and G.S. Mountain ${ }^{3}$
}

\section{GLOBAL SEA-LEVEL CHANGES}

Global sea-level (eustatic) changes profoundly influence the geologic record, affecting disciplines as diverse as stratigraphy, sedimentology, paleoecology, hydrogeology, climatology, and paleoceanography. Controversy has surrounded the age, magnitude, and mechanisms of Phanerozoic global sea-level changes. Exxon Production Research (EPR) revolutionized stratigraphic thought by proposing that seismic stratigraphy can be used to identify unconformity-bounded units (sequences) and to measure past sea-level changes (e.g., Vail et al., 1977). Subsequent studies by EPR have broadened the application of sequence stratigraphy to include outcrop, well, and seismic studies and have greatly increased the number of potential Triassic to Holocene sea-level events (e.g., Haq et al., 1987). The work of EPR has remained squarely at the center of controversy, in part, because the data base on which it is constructed is not entirely available to the public, although portions of the data have been released (e.g., Greenlee et al., 1988, 1992).

Although it is clear that packages of sediments (depositional sequences) bounded by unconformities can be objectively recognized in the stratigraphic record, the relationship of sequences to sea level must be established through empirical studies and modeling efforts (both forward and inverse; Christie-Blick et al., 1990; Reynolds et al., 1991). In relating sequences to sea level, it is important to realize that there are three types of sea-level change:

1. Eustatic changes are global sea-level variations with respect to the center of the Earth.

2. Relative sea-level changes are variations with respect to the crust (Posamentier et al., 1988). They result from changes in accommodation (the amount of space available for sediment to accumulate) caused by eustasy and tectonics (including thermal subsidence, loading, isostatic compensation, and flexure).

3. Changes in water depth or in the position of the shoreline are caused by variations relative to sea level and sediment input.

Geologists have historically equated relative sea-level changes with transgressions/regressions (horizontal shoreline movement). Shoreline position and water depth may vary independent of changes in relative sea-level because of variations in sediment input (Vail et al., 1977; Posamentier et al., 1988). Therefore, the response of continental margins to eustatic change will vary as a function of tectonics and sediment input (see Reynolds et al. 1991 for illustrations). Nevertheless, unconformities formed during intervals of increased rates of relative sea-level fall (e.g., Christie-Blick et al., 1990) and on passive continental margins are evidence of eustatic lowerings.

The academic community realized that integrated, public studies are needed to isolate the local effects of tectonics and sediment supply from past eustatic changes. The Second Conference on Scientific

\footnotetext{
${ }^{\prime}$ Mountain, G.S., Miller, K.G., Blum, P., et al., 1994. Proc. ODP, Init. Repts., 150: College Station, TX (Ocean Drilling Program).

${ }^{2}$ Department of Geological Sciences, Rutgers University, Piscataway. NJ 08855 , U.S.A.

${ }^{3}$ Lamont-Doherty Earth Observatory of Columbia University, Palisades, NY 10964,
}

Ocean Drilling (COSOD II, July 1987; Imbrie et al., 1988), a JOI/ USSAC Workshop (Watkins and Mountain, 1990), and the JOIDES Sea-Level Working Group (1992) recognized that sea-level studies require a global array of data and that ocean drilling could provide the most critical pieces of this array. These groups suggested focusing sea-level studies on three different time intervals: the Oligocene to Holocene "Icehouse World," when glacioeustatic changes were clearly operating; the mid-Cretaceous "Greenhouse World," which lacked significant ice sheets; and the Paleocene-Eocene "Doubthouse World," a time for which debate continues over the existence of ice sheets. They identified four tasks that sea-level research must accomplish: (1) test the synchrony of sea-level events; (2) estimate the amplitude of sealevel changes; (3) evaluate various models that seek to explain the stratigraphic response to sea-level oscillations; and (4) determine the mechanisms that control sea level.

COSOD II. JOI/USSAC, and the Sea-Level Working Group recommended a threefold approach to sea-level studies, incorporating data from passive continental margins, carbonate atolls/reef terraces, and deep-sea $\delta^{18} \mathrm{O}$ records (Imbrie et al., 1988; Watkins and Mountain, 1990; Sea-Level Working Group, 1992). The oxygen isotopic method potentially provides the most precise dates for glacioeustatic changes because it is recorded in deep-sea sections that contain magnetobiochronologic controls. However, the oxygen isotopic approach to sea-level history is complicated by temperature and local salinity changes, provides only approximate estimates of magnitudes, is largely restricted to the past $100 \mathrm{~m} . \mathrm{y}$., and contains no information about tectonically induced sea-level changes. The atoll approach potentially provides the most precise estimates of the magnitude of sea-level change (e.g., Fairbanks, 1989). However, in most situations, it is limited by problems in stratigraphic control, only records the eustatic highstands, and is restricted to Cretaceous and younger strata. In contrast, the record of sea-level fluctuations observed on continents and their margins spans a much longer time interval, certainly back to the beginning of the Paleozoic, and with limited resolution into the Precambrian.

In planning studies of "Icehouse" sea-level changes, we have begun to assemble the public data base that is needed to establish links between eustatic change, the deep-sea oxygen isotopic record, and the stratigraphy of siliciclastic margins. Siliciclastic sediments on passive continental margins document the relationship among changes in sediment supply, subsidence, and eustasy. Oxygen isotopes provide a chronology of sea-level changes, although not every oxygen isotopic fluctuation represents a glacioeustatic change. Studied separately, the margin and $\delta^{18} \mathrm{O}$ records yield incomplete understanding of the effects of sea-level change; together, they provide valuable measures of eustasy. We briefly review these two methods and provide an outline of the efforts that lead to drilling by Leg 150 .

\section{OXYGEN ISOTOPES AS INDICATORS OF EUSTATIC CHANGE}

Oxygen isotopic values recorded by foraminifers are a function of the temperature and seawater $\delta^{18} \mathrm{O}\left(\delta_{w}\right)$ values in which the organisms lived. For example, a foraminiferal $\delta^{18} \mathrm{O}$ increase may reflect either a drop in water temperature, a global $\delta_{w}$ increase caused by continental ice growth, or a local surface-water $\delta_{w}$ increase caused by 
increased evaporation or reduced precipitation. Glacioeustatic fluctuations cause global $\delta_{w}$ changes that are recorded by benthic and planktonic foraminifers; the challenge is to isolate ice volume from temperature and local isotopic changes. Concomitant changes in benthic and low-latitude (nonupwelling) planktonic foraminiferal $\delta^{18} \mathrm{O}$ records have been used successfully as a Pleistocene ice-volume indicator (Shackleton and Opdyke, 1973, 1976). Further studies validate this technique for the Pleistocene-Holocene. Covariance between benthic and western equatorial Pacific planktonic foraminiferal $\delta^{18} \mathrm{O}$ records was $1.2 \%-1.3 \%$ from the last glacial maximum to the present (Shackleton and Opdyke, 1973). This predicts a sea-level rise of 109-118 m (Fairbanks and Matthews, 1978), similar to the $121 \pm 5 \mathrm{~m}$ established by Fairbanks (1989). We have used covariance between benthic and low-latitude planktonic foraminiferal $\delta^{18} \mathrm{O}$ signals as a proxy for prePleistocene ice-volume changes (Miller et al., 1987, 1991), although pre-Pleistocene sea-level magnitudes can only be roughly estimated. ${ }^{4}$

The Oligocene to Holocene is an interval in which eustatic estimates derived from patterns of coastal onlap on passive continental margins (e.g., Haq et al., 1987) may be directly compared with eustatic estimates obtained from $\delta^{18} \mathrm{O}$ studies (Fig. 1). Oxygen isotopic records and glaciomarine sediments indicate that large continental ice sheets have been present on Antarctica since at least the earliest Oligocene (ca. $35 \mathrm{Ma}$; see summary in Miller et al., 1991). These ice sheets waxed and waned numerous times during the Oligocene to Holocene "Icehouse World," resulting in estimated sea-level changes of up to $120 \mathrm{~m}$. Covariance between benthic and low-latitude (nonupwelling) planktonic foraminiferal $\delta^{18} \mathrm{O}$ records provide the strongest evidence for the timing of ice-volume changes for this interval. However, previous attempts to use covariance between benthic and surface-water $\delta^{18} \mathrm{O}$ values have suffered from inadequate low-latitude data (see summary in Miller et al., 1991).

Miller et al. (1991) and Wright and Miller (1992) identified $12 \delta^{18} \mathrm{O}$ increases (all $>0 . \%$ ) recorded by benthic foraminifers between ca. 35 and $8 \mathrm{Ma}$ (Zones Oil-Oi2 and Mi1-Mi7; Fig. 1). Six of these also occur in tropical or subtropical planktonic foraminifers (the other six lack suitable material ${ }^{5}$ ). Such covariance between the benthic and planktonic $\delta^{18} \mathrm{O}$ records may best be attributed to global $\delta_{w}$ changes resulting from ice growth; Miller et al. (1991) and Wright and Miller (1992) interpreted these $12 \delta^{18} \mathrm{O}$ increases as glacioeustatic lowerings. They supported this position by linking benthic foraminiferal $\delta^{18} \mathrm{O}$ increases at 35.8, 32.5, and ca. 23.5 Ma (=Zones Oi1, Oi2, and Mi1), with intervals of glacial sedimentation on or near Antarctica and with $\delta^{18} \mathrm{O}$ increases in subtropical planktonic foraminifers. In addition, they showed that good agreement exists in timing and amplitude between middle Miocene benthic foraminiferal $\delta^{18} \mathrm{O}$ records and a western equatorial planktonic foraminiferal $\delta^{18} \mathrm{O}$ record, reflecting substantial ice volume increases at about 16.1 (Zone Mi2), 13.6 (Zone Mi3), and 11.3 (Zone Mi5) Ma. Finally, as a working hypothesis, they correlate these 12 isotopic increases with the 12 sequence boundaries (= inferred eustatic lowerings) of Haq et al. (1987).

Additional low-latitude planktonic foraminiferal records are needed to establish that all of the benthic foraminiferal $\delta^{18} \mathrm{O}$ increases documented by Miller et al. (1991) and Wright and Miller (1992) are related to glacioeustatic change. In addition, higher frequency "Milankovitch scale" variations ( $104-10^{5}$ year) are embedded in the lower frequency $\delta^{18} \mathrm{O}$ changes (Pisias et al., 1985). Ongoing studies are beginning to unravel the oxygen isotopic record in the Oligocene-Miocene; these should provide a more reliable proxy of glacioeustasy.

\footnotetext{
${ }^{4}$ Using the Pleistocene ice-volume $\delta^{18} \mathrm{O}$ calibration, we have estimated that sea level was glacioeustatically lowered by $35-100 \mathrm{~m}$ during Oligocene-Miocene intervals of benthic and planktonic increases (Miller et al., 1987, 1991).

${ }^{5}$ Tropical planktonic $\delta^{18} \mathrm{O}$ values increase during the Mi2 (ca. 16.1 Ma), Mi3 (13.6 Ma), and Mi5 (11.3 Ma) events; subtropical planktonic records are available to document the Oil (ca. $35.8 \mathrm{Ma}$ ), Oi2 (ca. 32.2 Ma), and Mil (ca. 23.7 Ma) events. The increases associated with Oi2b (28.0 Ma), Mila (ca, $21 \mathrm{Ma}$ ), Milb (ca. $18 \mathrm{Ma}$ ), Mi4 (ca. $12.6 \mathrm{Ma}$ ). Mi6 (ca. 9.6 $\mathrm{Ma}$ ), and Mi7 (ca. 8.5 Ma) events lack suitable planktonic data (Miller et al., 1991).
}

\section{EUSTATIC RECORDS ON PASSIVE CONTINENTAL MARGINS}

The passive margin record of sea-level change can be deciphered in either of two ways: (1) by measuring changes in shoreline position or water depths inferred from facies successions (e.g., Bond, 1978; Hancock and Kauffman, 1979), or (2) by analyzing regional unconformities with chronostratigraphy (e.g., Aubry, 1985; Miller et al., 1990) or sequence stratigraphy (e.g., Vail et al., 1977; van Wagoner et al., 1987). Because the formation of major stratal discontinuities requires the lowering of depositional base level, this unconformity/ sequence stratigraphic approach is less sensitive to variations in sediment supply than is the position of the shoreline (Christie-Blick et al., 1990). However, sequence stratigraphy has its limitations: although it provides a great deal of information about the timing of relative sea-level changes, it is less specific about magnitude.

A transect of boreholes is required for estimating both the ages of sequence boundaries and the amplitudes of relative sea-level change associated with the sequences. Both the JOI/USSAC Workshop and the Sea-Level Working Group concluded that a transect of holes across passive margins is needed to address three issues relating to sea-level history:

1. Timing. Sufficient chronostratigraphic precision (i.e., $\ll<1$ m.y.) can only be attained along a transect for the following reason: stratal geometry is most clearly expressed in marginal marine to shelf environments, but key taxa for age correlations are typically absent from these environments. Biostratigraphic markers and more continuous pelagic deposition are likely found in the bathyal setting of a continental slope; however, sequence geometry that clearly relates to sea-level control is lacking so far below the depositional base level. The key to overcoming this shallow-water/deep-water paradox is to have highquality seismic data that establishes the physical correlation between the two environments; one identifies the key sequence boundaries, the other provides the definitive ages.

2. Amplitudes and Rates. The amount of total subsidence (the sum of cooling, compaction, isostatic, and flexural changes through time) that has occurred on passive margins is larger than any eustatic oscillation. To estimate the amplitude and rates of sea-level changes, therefore, the subsidence history must be known with considerable accuracy, which can only be achieved by sampling along a dip line transect that has experienced a range of thermal, loading, and bending histories. In addition, paleobathymetric estimates based on faunal assemblages are an equally essential component in calculating the amplitudes of eustatic changes; their precision will be greatly enhanced by multiple samples along the transect of a single depositional surface.

3. Response. Sequence stratigraphic models (e.g., Posamentier et al., 1988; van Wagoner et al., 1987) have generated considerable interest in the academic and industrial communities regarding the response of passive margin and epicontinental seas to sea-level variations. The detail and complexity of these facies models can only be evaluated by drilling a complete transect of boreholes from the coastal plain to the deep sea. Although the response of deep-sea sedimentation to sea-level fluctuations is not clear (e.g., Tucholke, 1981), the relationship is critical for understanding deep-sea processes and global sedimentary budgets.

In developing their synthesis of Triassic-Holocene sea level, EPR also focused on these three issues. Haq et al. (1987) provided a chronology of sea-level changes, Greenlee and Moore (1988) tested the sensitivity of the amplitude of sea-level change, and Posamentier et al. (1988) and van Wagoner et al. (1987) provided models for the response. The EPR cycle chart is a eustatic history based on seismic, well-log, and outcrop stratigraphy; however, as noted above, corroborating documentation is largely unavailable. Evaluating global sealevel changes requires an extensive, publicly available data base, and it was for the purpose of developing and interpreting just such a body of data that Leg 150 was conceived. 


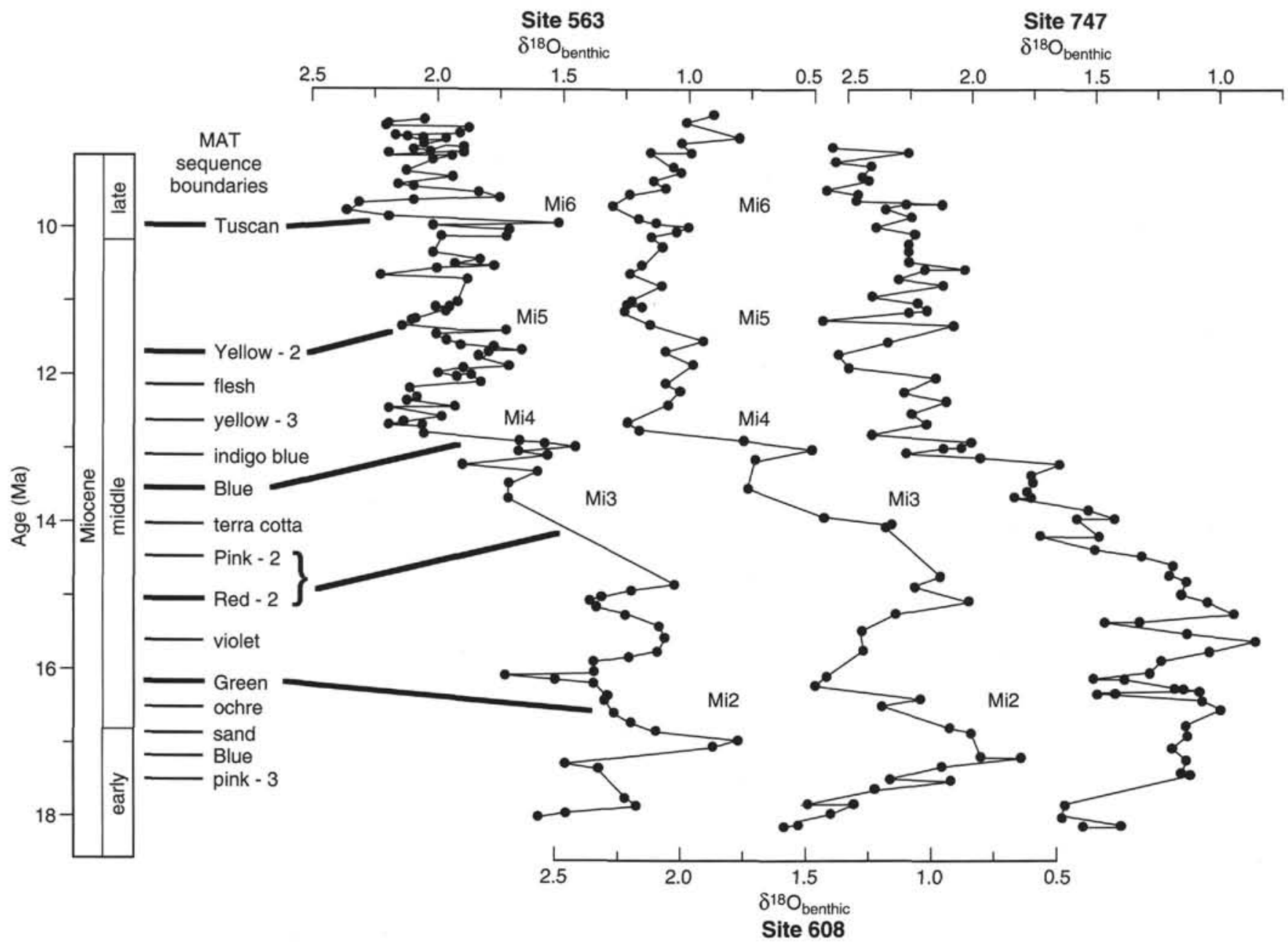

Figure 1. Correlation of the Miocene oxygen isotope zones of Miller et al. (1991) and Wright and Miller (1992) from Sites 563, 608, and 747 with candidate sequence boundaries noted by Greenlee et al. (1992) (heavy lines) and candidate sequence boundaries identified on the shelf (thin lines) (G.S. Mountain, K.G. Miller, and N. Christie-Blick, unpubl, data, 1990). Although Red-2 and Pink-2 were recognized as separate sequence boundaries by Greenlee et al. (1992), their ages could not be distinguished.

\section{THE NEW JERSEY SEA-LEVEL TRANSECT}

The U.S. Mid-Atlantic Margin (New Jersey-Delaware-Maryland; Figs. 2-3) represents an especially suitable area for evaluating the effects of glacioeustatic changes on continental margin sedimentation. Seismic stratigraphic studies of the New Jersey continental shelf (Greenlee et al., 1988, 1992; Greenlee and Moore, 1988; G.S. Mountain, K.G. Miller, and N. Christie-Blick, unpubl. data, 1990) reveal numerous Oligocene-Miocene depositional sequences. In addition to the clear seismic expression of sequences from the "Icehouse World," this region has several advantages that include

1. high late Oligocene to Miocene sedimentation rates (tens to hundreds of meters per million years) that allow detailed resolution of stratal relationships (e.g., Greenlee et al., 1988; Greenlee and Moore, 1988) (Fig. 4);

2. good biostratigraphic (Poag, 1985; Olsson and Wise, 1987; Poore and Bybell, 1988; among others) and Sr-isotopic stratigraphic controls (Miller et al., 1990; Sugarman et al., 1993);

3. a well-defined thermal subsidence history (e.g., Steckler and Watts, 1982);

4. a substantial body of useful data (including seismics, wells, and outcrops), which allow a well-conceived study to focus on the crucial, testable issues (Fig. 3; Hathaway et al., 1976; Poag, 1978, 1980, 1985;
Kidwell, 1984; Miller et al., 1985, 1990; Owens and Gohn, 1985; Olsson et al., 1987; Greenlee et al., 1988).

Upper Oligocene to Holocene sequences on the New Jersey continental shelf are strongly progradational, with well-developed clinoforms (Fig. 4). These clinoforms are sequence boundaries recognized by onlap, erosional truncation, toplap, and downlap. Ages of sequence boundaries are best determined at two locations: (1) at their deep-water correlatives where biostratigraphic resolution is optimized, and (2) at the toe of each clinoform, where physical stratigraphy indicates that the hiatus is minimized and the lowstand systems tract is best developed. In addition, it is necessary to drill the landward side of the clinoform inflection point (i.e., the "depositional coastal break" of Vail, 1987) to provide facies and paleodepths of the target sequence as well as the thickest record of the underlying sequence. Relative sea-level changes can be estimated for each sequence by modeling subsidence at sites landward and at the toe of the clinoform inflection points (Greenlee et al., 1988).

G.S. Mountain, K.G. Miller, and N. Christie-Blick (unpubl. data, 1990) designed the New Jersey Sea-level Transect to focus on the Oligocene-Holocene interval that is best represented on the U.S. MidAtlantic Margin. Using the approach outlined above, drilling along the transect was to sample major shelf sequences landward of the clinoform inflection points, at the toes of the clinoforms, and on the 


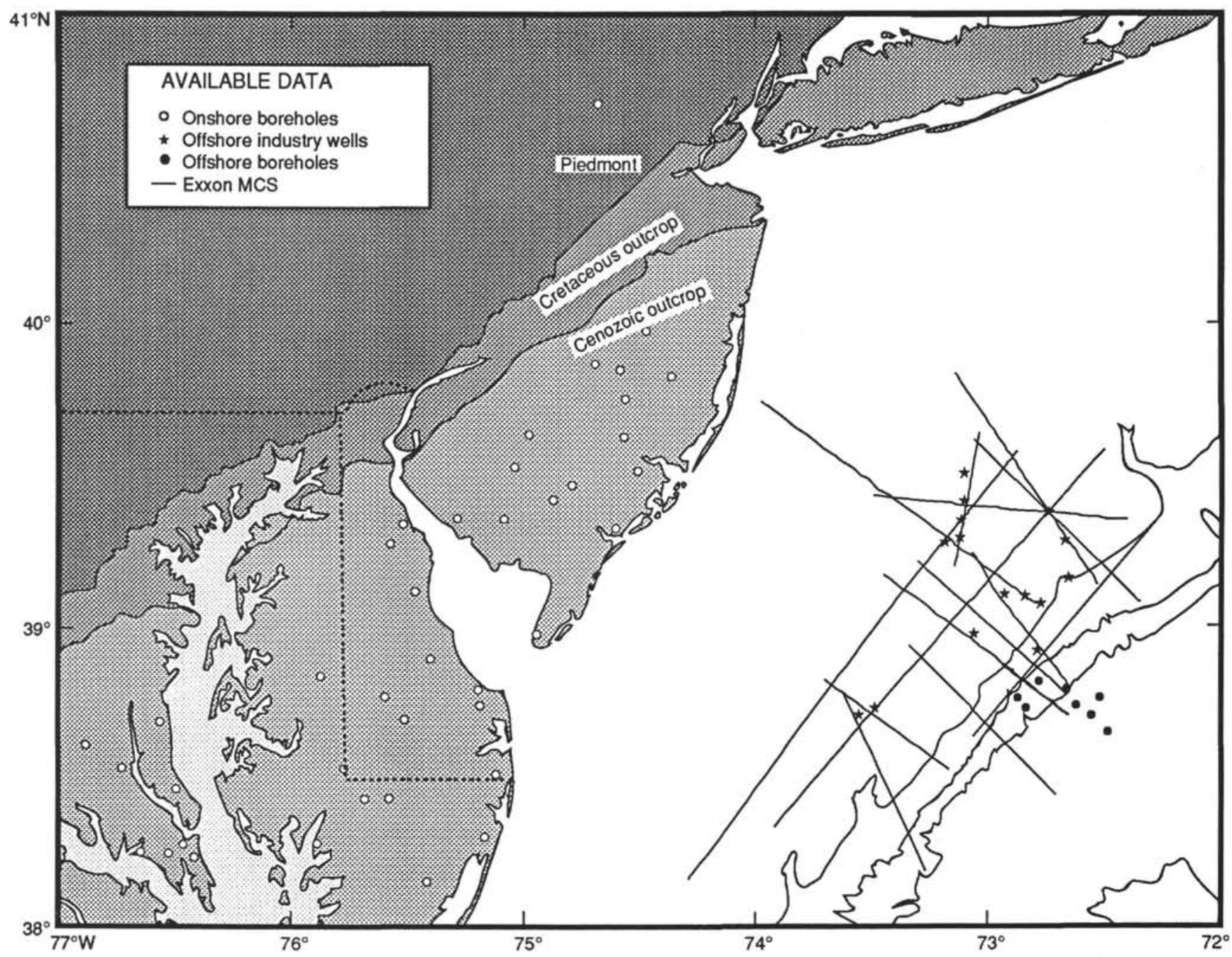

Figure 2. Location map of Exxon multichannel seismic lines, industry wells (solid stars), slope boreholes (solid circles; this includes DSDP, ASP, and AMCOR sites), and previously drilled onshore wells and boreholes (open circles).

continental slope. Significant progress has been made in planning the transect:

1. Greenlee et al. (1992) reevaluated $1100 \mathrm{~km}$ of Exxon multichannel seismic (MCS) profiles from the Mid-Atlantic Margin (Fig. 2 ) and presented age estimates for the six major Miocene sequence boundaries defined in Greenlee et al. (1988; Tuscan to Bice-1; Figs. 5-6) by using available industry wells. Biostratigraphic resolution is coarse in these wells, and the age estimates have large uncertainties ( $\pm 1 \mathrm{~m}$.y. or greater). Two well-log transects tied to Exxon seismic data provide insight into the lithofacies and sequence stratigraphic architecture (Greenlee et al., 1992).

2. We collected and processed $3750 \mathrm{~km}$ of marine seismic reflection profiles using the Maurice Ewing in November 1990 (Figs. 3-4).

3 . We integrated the shelf data with paleontologic samples and logs from available onshore wells and outcrops (Sugarman et al., 1993) and used these studies to plan and implement the drilling of three additional onshore boreholes (see below).

4. We have tied our shelf seismic grid to a number of wells and boreholes (DSDP 612, COST B3, ASP14, and ASP15) drilled previously and to outcrop samples collected by the Alvin in 1989 (K.G. Miller, unpubl. data, 1993).

5. A detailed Sea Beam bathymetric map was generated from data collected on two Atlantis II cruises (August 1989 and December 1989;
W.B.F. Ryan and K.G. Miller, co-chiefs) that allowed us to locate slope boreholes (proposed Sites MAT10-13, 15, and 16) for drilling by JOIDES Resolution.

Based on the geometry of the upper Oligocene to Miocene sequences revealed in the Exxon and Ewing data sets, the transect can be divided into four geographic areas (Figs. 3-4):

1. Inner shelf $(<50 \mathrm{~m})$ and coastal plain, which contain the clinoform inflection points for the upper Oligocene to lower Miocene (proposed Sites MAT1-3, Island Beach borehole).

2. Present-day middle shelf $(50-100 \mathrm{~m})$, which contains the clinoform inflection points for the middle Miocene (proposed Sites MAT4-7).

3. The present-day outer continental shelf $(100-200 \mathrm{~m})$, which contains the clinoform inflection points for the upper Neogene (upper Miocene-Pleistocene) sequences; hence, drilling on the outer shelf will focus on sequences younger than $10 \mathrm{Ma}$ (proposed Sites MAT8, 9 , and $9 \mathrm{~A})$.

4. The present-day continental slope, which contains the pelagic correlatives to sequence boundaries observed beneath the adjacent shelf (Leg 150 Sites 902-904 and 906; Fig. 7).

As outlined here, the transect is an integration of ODP offshore, supplementary nearshore, and onshore drilling. The transect is in- 


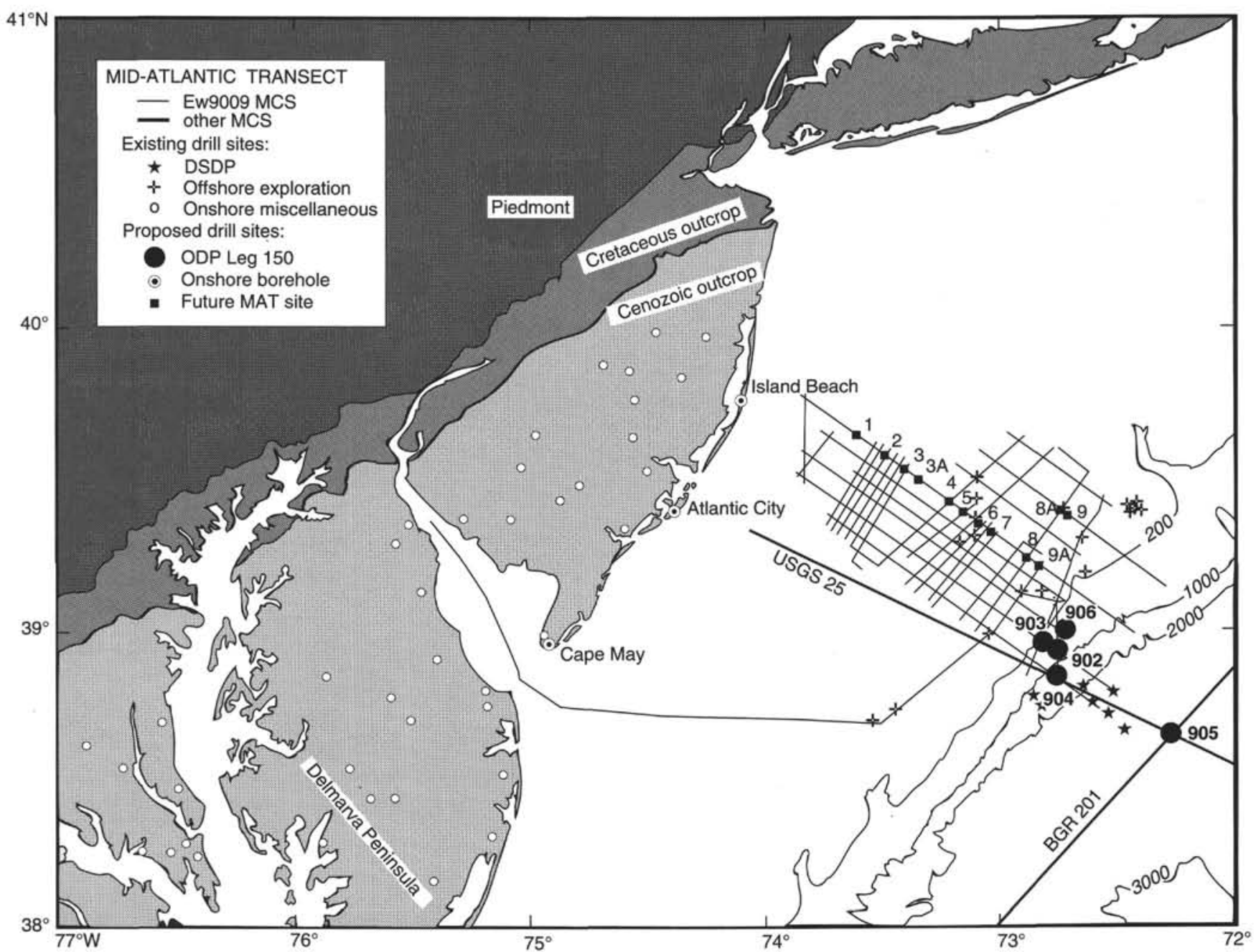

Figure 3. Location map and track chart for multichannel seismic profiles collected during Cruise Ew9009 (light lines) and from other sources (heavy lines), proposed boreholes MAT1-9, Leg 150 Sites 902 through 906, proposed onshore boreholes (circles with solid centers), and previous onshore wells and boreholes (open circles).

tended to document the response of passive continental margin sedimentation to glacioeustatic changes during the late Oligocene to Miocene "Icehouse World" (Miller et al., 1991).

The seismic geometries of Paleocene-Eocene sequences on the New Jersey Margin are not as well developed as the overlying "Icehouse" section. These "Doubthouse" sequences are thinner, and clinoforms, if any, were deposited landward of the present-day outcrop (i.e., they have been eroded). Thus, it is difficult to derive estimates of sea-level amplitude from the Paleocene-Eocene record of this region. However, numerous Paleocene-Eocene unconformities on this margin apparently record relative sea-level lowerings (e.g., Olsson and Wise, 1987; Miller et al., 1990; Aubry, 1991). In addition to its primary focus on the upper Oligocene-Miocene "Icehouse" sequences, the New Jersey Sea-level Transect will penetrate Eocene sequences on the coastal plain and slope and constrain the timing of "Doubthouse" unconformities.

Leg 150 was originally designed to drill on the continental shelf (proposed Sites MAT4-9) and slope (proposed Sites MAT10-12). However, safety concerns led to disapproval of drilling in less than $200 \mathrm{~m}$ water depth, with the result that five sites were drilled during Leg 150 on the slope and rise. Along with two onshore sites drilled at Island Beach and Atlantic City, New Jersey (see Chapters 1 and 2 in Miller et al., 1994), plus a third at Cape May, New Jersey, planned for
Spring 1994, these sites constitute the end-points of a marginwide transect. One of the strengths of the research performed during Leg 150 is its ability to date the seismic sequences observed on the shelf in a deeper water setting, whereas the onshore sites provide information on timing and shallower water facies (primarily the regressive Highstand Systems Tracts; Sugarman et al., 1993). However, drilling on the shelf is needed to complete the transect because OligoceneHolocene sequences are fully developed only on the shelf.

\section{DETERMINING AGE OF SHELF SEISMIC SEQUENCES WITH SLOPE DRILLING}

Seismic sequences revealed beneath the shelf can be traced from the continental shelf to the continental slope. The seismic grid that makes these slope-to-shelf correlations possible is based primarily on a high-resolution MCS grid using the Maurice Ewing in November 1990 (Figs. 3-4), a slope single-channel seismic (SCS) grid obtained during the same cruise (Fig. 7), and MCS data released by Exxon Production Research (EPR; Fig. 2). The Ewing seismic grid (Cruise Ew9009) comprises $3700 \mathrm{~km}$ of profiles (data archived in ODP data bank). Two-thirds of these data (Figs. 3 and 7) are 120-channel, tuned air-gun array profiles across the shelf that complement the Exxon data and tie them to their wells; the rest are single-channel water-gun data 


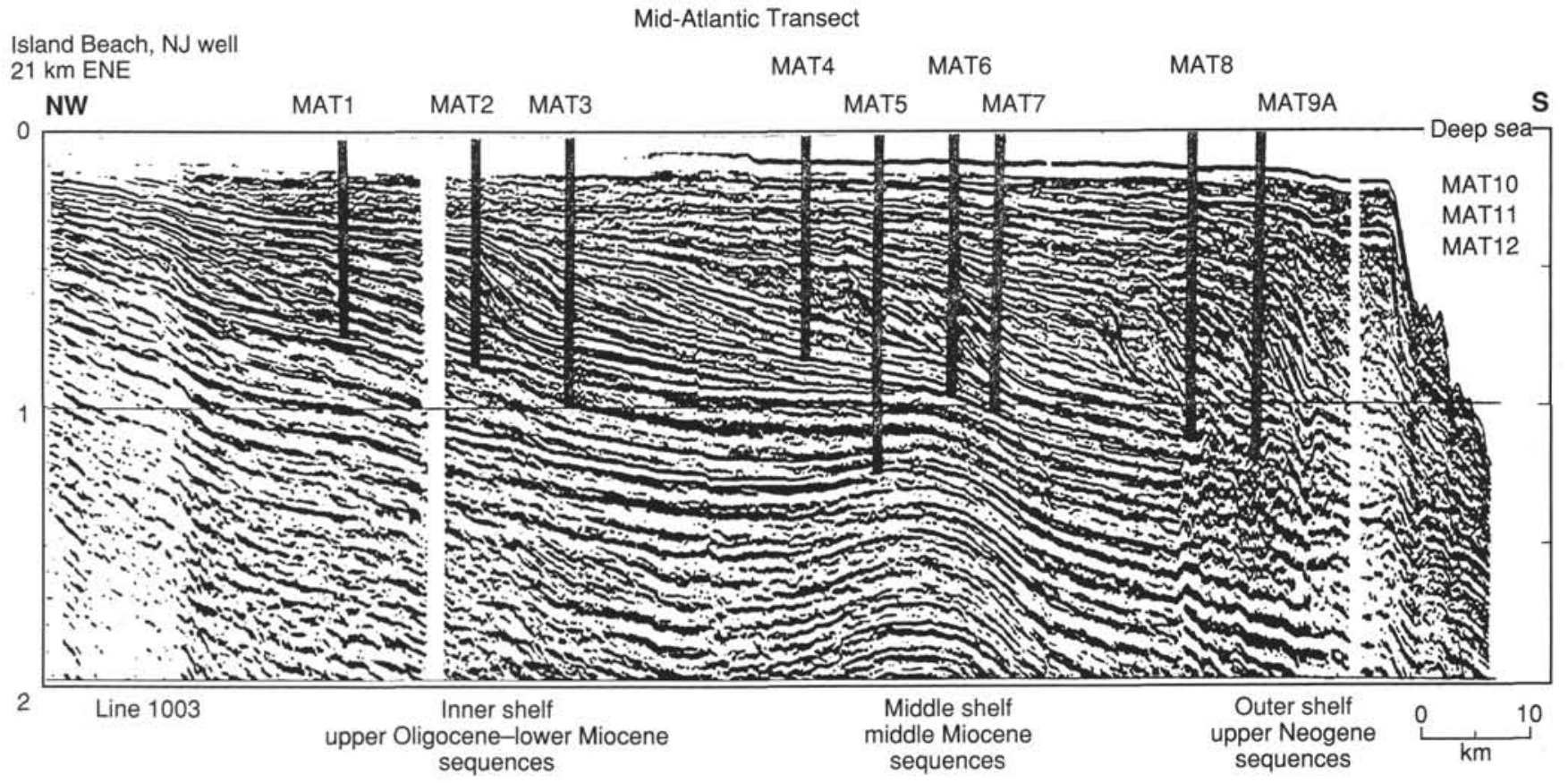

Figure 4. The Mid-Atlantic Transect. Compressed Cruise Ew9009 Line 1003 showing locations of shelf sequences and proposed shelf boreholes MAT1-9.

(Fig. 7) on the upper continental slope, tying the shelf stratigraphy to a number of boreholes drilled previously and to outcrop samples collected in 1989 by the Alvin (K.G. Miller, unpubl. data, 1993). The Ew9009 profiles have better seismic resolution than do those from the Exxon grid; therefore, G.S. Mountain, K.G. Miller, and N. ChristieBlick (unpubl. data, 1990) used these data to confirm the major sequence boundaries of Greenlee et al. $(1988,1992)$ and to identify several other surfaces as probable sequence boundaries (Figs. 1 and 5).

We speculate that the major sequence boundaries identified on our seismic grids correlate with oxygen isotopic increases linked to glacioeustatic lowerings (Fig. 1). Furthermore, we propose that these sequence boundaries correlate with hiatuses on the coastal plain (Sugarman et al., 1993) and continental slope. Stratal terminations observed in the Ew9009 seismic grid suggest that further study may locate additional sequence boundaries. Each of these confirmed and potential sequence boundaries can be traced directly from the continental shelf to our slope sites, where they can be dated in a pelagic setting.

The primary goal of Leg 150 is to date major Oligocene to Holocene unconformities on the New Jersey Margin and to evaluate their correlation with glacioeustatic age estimates obtained from the $\delta^{18} \mathrm{O}$ record. Secondary goals are to determine the ages of major Eocene "Doubthouse" unconformities and to evaluate the relative importance of along-slope vs. downslope sediment transport processes and establish their links to eustatic variations. This information will contribute to the final objectives of the entire transect, which will be completed with shelf drilling. At that time, it will be possible to estimate the amplitudes and rates of the sea-level change and to assess the stratigraphic response of glacioeustatic forcing in terms of sequence architecture and facies successions.

\section{ONSHORE DRILLING AS PART OF TRANSECT STRATEGY}

As part of the New Jersey Sea-level Transect, three holes are being drilled on the onshore coastal plain with the support of the U.S. National Science Foundation (Earth Science Division, Continental Dynamics Program and Ocean Science Division, Ocean Drilling Program). Onshore drilling is a collaborative effort among Rutgers University, Lamont-Doherty Earth Observatory, the U.S. Geological Sur- vey, and the New Jersey State Geological Survey. PCOM endorsed the onshore drilling as an ODP-related activity (Leg 150X). The goal of onshore drilling is to recover updip counterparts. In addition, the onshore boreholes provide continuous coring of "Doubthouse" sequences (Paleocene-Eocene). The first shore-based site was completed to $1223 \mathrm{ft}$. at Island Beach State Park, New Jersey, in May 1993; it penetrated the Maastrichtian at total depth. The second at Atlantic City, New Jersey, was spudded and completed during Leg 150. The third proposed site will be drilled at Cape May, New Jersey, in Spring 1994. Each site was logged by BPB Instruments under the guidance of the ODP Borehole Geophysics facility at Lamont-Doherty Earth Observatory. Initial results from the first two sites are included in Chapters 1 and 2 of Volume 150X (Miller et al., 1994); the results from the third site (Cape May) will be included in a subsequent ODP publication.

\section{SLOPE AND CONTINENTAL RISE PROCESSES}

Leg 150 drilling was at first designed to focus primarily on the direct effects of sea-level change on shallow-water facies. However, by drilling four boreholes on the slope and one on the rise, the scientists of Leg 150 are in an excellent position to evaluate the indirect effects of sea-level change on deep-sea sedimentation. Since Heezen et al. (1966) showed that abyssal circulation shapes the U.S. continental rise, researchers have debated the relative roles of endogenous (e.g., currents) vs. exogenous (e.g., sea level) mechanisms of slope failure and rise sedimentation. Seismic stratigraphic studies (e.g., Poag, 1985; Mountain and Tucholke, 1985) have documented that canyons similar to those entrenched into the modern rise (e.g., Hudson and Wilmington canyons) are absent in lower Neogene to Paleogene strata off North America. Consequently, if the adjacent shelf and slope contributed substantial volumes of sediment to the rise during eustatic lowstands, mechanisms of both transport and deposition are as yet unclear. Localized slope failure provides a source of rise sediments as well as potential conduits to deliver sediment to the rise. Slope failure may be attributable to mechanisms other than sea-level change, such as (1) seismicity (Heezen and Ewing, 1952); (2) activity of bottom-dwelling fauna (Shepard and Dill, 1966); (3) undercutting by erosive bottom currents (Paull and Dillon, 1980); (4) groundwater sapping caused by changing in situ pore pressure (Robb et al. 1981); 


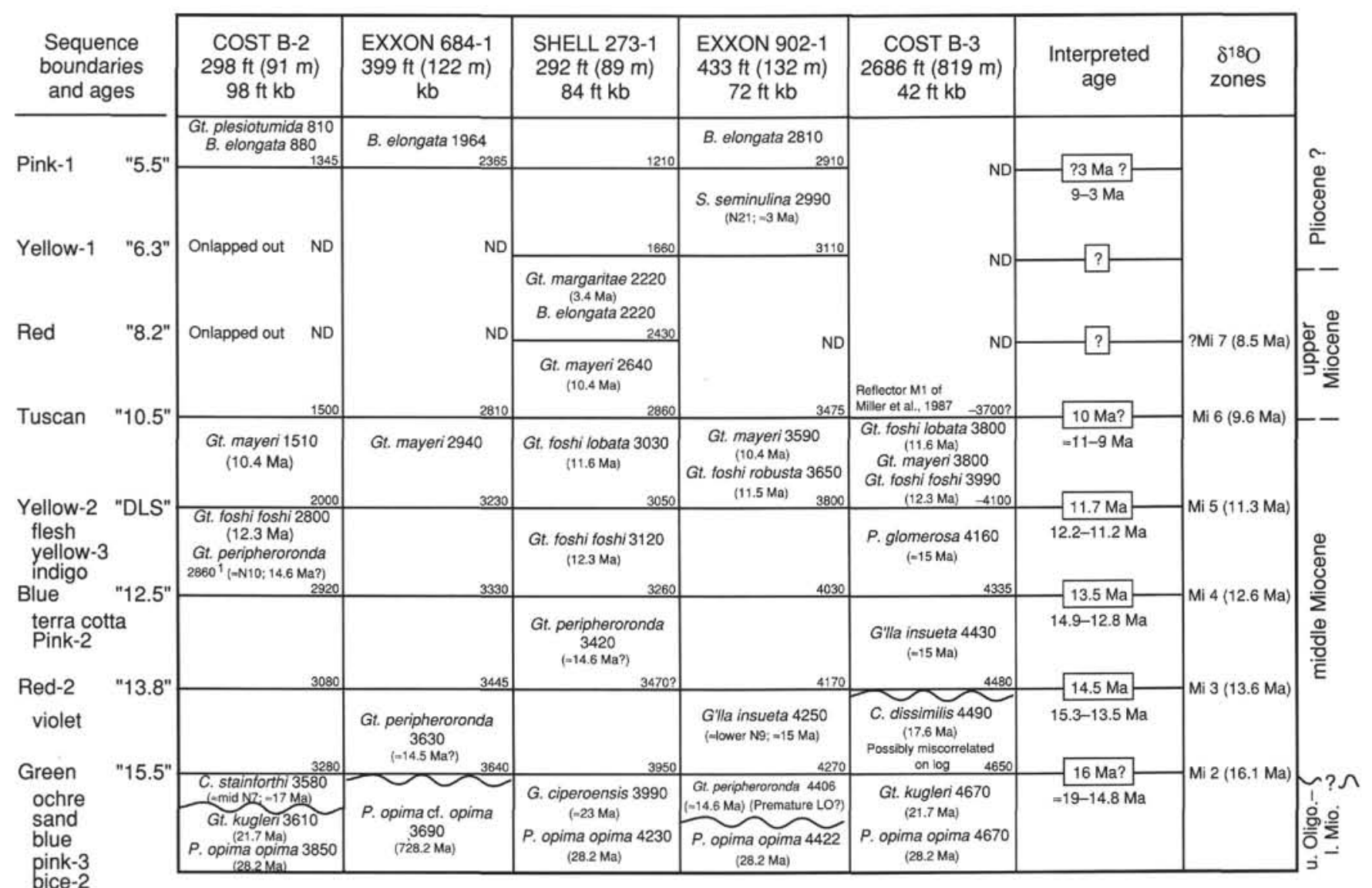

red-3

red-4

Figure 5. Late Oligocene-Miocene biostratigraphy and age estimates for five industry wells on the New Jersey continental shelf and slope. All depths are in feet below kelly bushing. The depths to sequence boundaries were derived from seismic well-log ties and velocity surveys except for Tuscan at COST B-3. ND $=$ not discerned. Oxygen isotope zones after Miller et al. (1991). Interpreted ages were derived from the age-depth diagram (Fig. 6, modified after Greenlee et al. [1992]); their sequence boundaries (e.g., Tuscan) are left justified, whereas additional candidate sequence boundaries (e.g., flesh; G.S. Mountain, K.G. Miller, and N. Christie-Blick, unpubl. data, 1990) are to the right. The ages in quotes are after Haq et al. (1987).

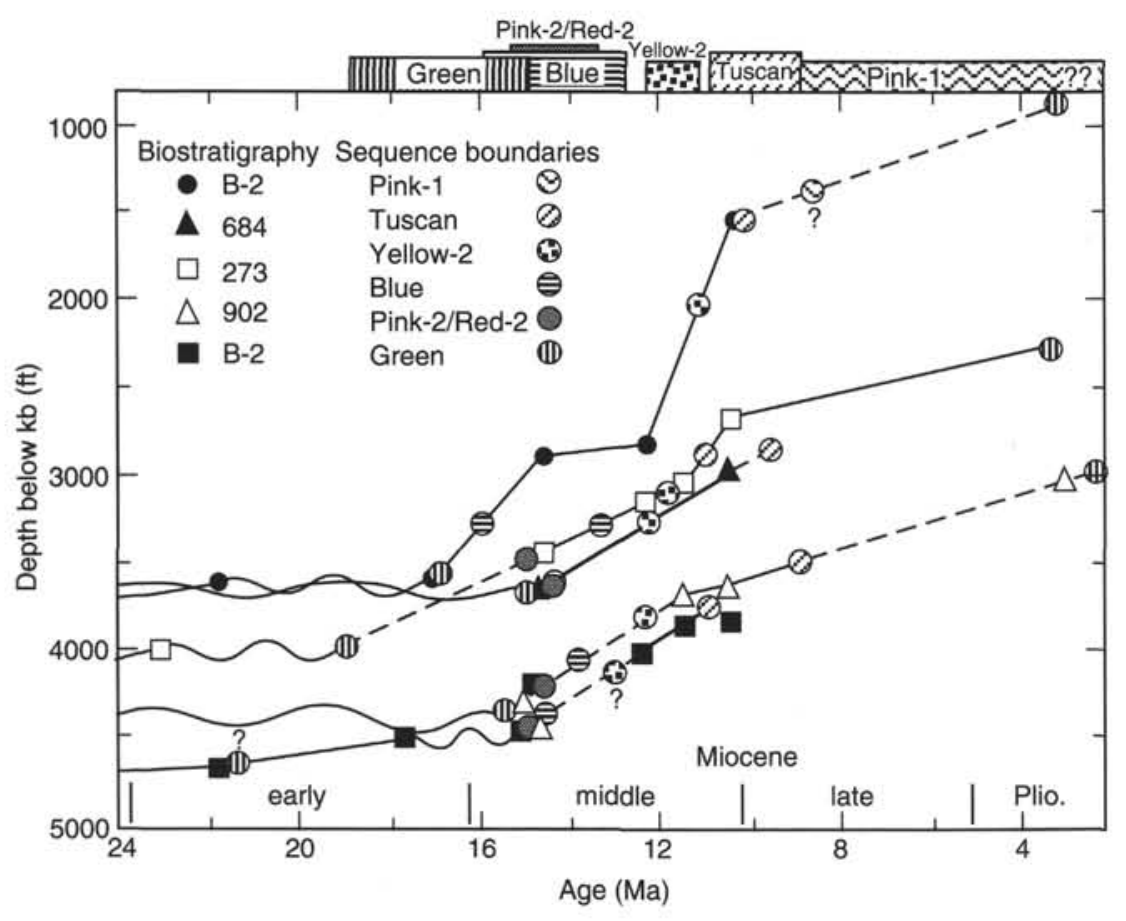

Figure 6. Age-depth diagram for five wells, New Jersey continental shelf and slope. Wavy lines indicate hiatuses. The age depth diagrams were constructed using the depths and ages of planktonic foraminiferal last occurrences shown in Figure 5. The depths of the seismic reflections to the sequences boundaries were plotted on these lines, and the ages of the sequences estimated. The age estimates are given on the top margin. After Greenlee et al. (1992). 
Figure 7. Detailed location map of the outer continental shelf and slope region showing Cruise Ew9009 multichannel (heavy) and single-channel (light) seismic lines, as well as other seismic lines (dashed) and the location of DSDP, COST, AMCOR, ASP, and oil company exploration wells. Bathymetric contours in meters.

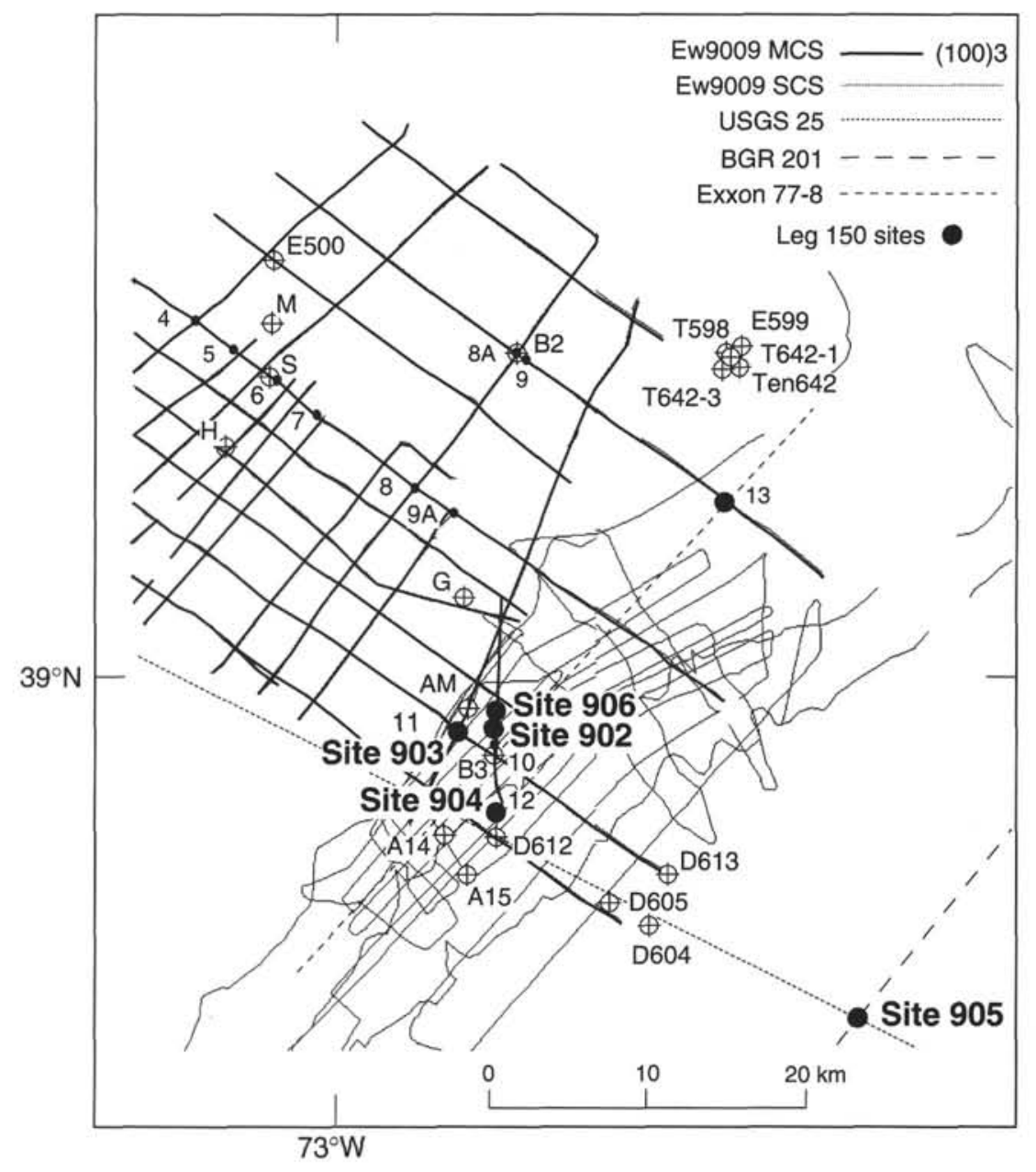

rise (Site 905) is at the same location as Site NJ-6 from DSDP Leg 95 and is designed to monitor the response of sedimentation on the rise to changes in sea-level and deep-water circulation.

\section{SUMMARY}

The New Jersey Sea-level Transect is an integrated set of boreholes planned for the U.S. mid-Atlantic region. The goal is to document the continental margin record of the Oligocene-Holocene "Icehouse World" by determining the age of major unconformities, by acquiring the data base needed for modeling the amplitudes and rates of relative sea-level changes, and by documenting facies variations associated with oscillations of sea level. Secondary objectives are to determine the ages of major Eocene "Doubthouse" unconformities and to evaluate the role of sea-level change on continental slope and rise sedimentation. This transect will encompass drilling in four settings with the following objectives:

1. Onshore coastal plain: to date Eocene-Miocene sequences and provide facies information on upper Oligocene-Miocene units landward of their clinoform inflection points. Drilling at Island Beach and Atlantic City, New Jersey, was completed in 1993, and drilling at Cape May, New Jersey, will be completed in 1994 as an ODP-related project involving Rutgers, L-DEO, the USGS, and the New Jersey State Geological Survey.

2. Continental shelf: to recover the most complete record of relatively shallow-water facies deposited during the "Icehouse World." The TAMU Safety Panel has postponed shelf drilling by the JOIDES Resolution until pollution prevention and safety concerns are examined in detail. 
3. Continental slope: to sample boundaries of depositional sequences that are seismically imaged on the shelf but which can be dated with greater precision on the slope. Four sites were drilled and logged during ODP Leg 150 in water depths between 444 and 1134 $\mathrm{m}$; each was chosen to recover an especially complete and thick portion of the Oligocene-Holocene interval.

4. Uppermost continental rise: to compare the age and character of downslope and margin-parallel sediment transport events to the history of eustatic change. During Leg 150 , one site at $2709 \mathrm{~m}$ was drilled and logged.

\section{REFERENCES}

Aubry, M.-P., 1985. Northwestern Europe magnetostratigraphy, biostratigraphy and paleogeography: calcareous nannofossil evidence. Geology, 13:198-202.

, 1991. Sequence stratigraphy: eustasy or tectonic imprint? J. Geophys. Res., 96:6641-6679.

Bond, G.C., 1978. Speculations on real sea-level changes and vertical motions on continents at selected times in the Cretaceous and Tertiary Periods. Geology, 6:247-250.

Christie-Blick, N., Mountain, G.S., and Miller, K.G., 1990. Stratigraphic and seismic stratigraphic record of sea-level change. Sea-level Change: Washington (National Academy Press), 116-140.

Fairbanks, R.G., 1989. A 17,000-year glacio-eustatic sea level record: influence of glacial melting rates on the Younger Dryas event and deep-ocean circulation. Nature, 342:637-642.

Fairbanks, R.G., and Matthews, R.K., 1978. The marine oxygen isotope record in Pleistocene coral, Barbados, West Indies. Quat. Res. (N.Y.), 10:181-196.

Greenlee, S.M., Devlin, W.J., Miller, K.G., Mountain, G.S., and Flemings, P.B., 1992. Integrated sequence stratigraphy of Neogene deposits, New Jersey continental shelf and slope: comparison with the Exxon model. Geol. Soc. Am. Bull., 104:1403-1411.

Greenlee, S.M., and Moore, T.C., 1988. Recognition and interpretation of depositional sequences and calculation of sea level changes from stratigraphic data-offshore New Jersey and Alabama Tertiary. In Wilgus, C.K., Posamentier, H., Ross, C.A., and Kendall, C.G.St.C. (Eds.), Sea Level Changes: an Integrated Approach. Spec. Publ--Soc. Econ. Paleontol. Mineral., 42:329-353.

Greenlee, S.M., Schroeder, F.W., and Vail, P.R., 1988. Seismic stratigraphic and geohistory analysis of Tertiary strata from the continental shelf off New Jersey: calculation of eustatic fluctuations from stratigraphic data. In Sheridan, R.E., and Grow, J.A. (Eds.), The Atlantic Continental Margin. Geol. Soc. Am., Geol. of North Am. Ser., 437-444.

Hancock, J.M., and Kauffman, E.G., 1979. The great trangressions of the Late Cretaceous. J. Geol. Soc. London, 136:175-186.

Haq, B.U., Hardenbol, J., and Vail, P.R., 1987. Chronology of fluctuating sea levels since the Triassic. Science, 235:1156-1167.

Hathaway, J.C., Schlee, J., Poag, C.W., Valentine, P.C., Weed, E.G.A., Bothner, M.H., Kohout, F.A., Manheim, F.T., Schoen, R., Miller, R.E., and Schultz, D.M., 1976. Preliminary study of the 1976 Atlantic Margin Coring Project of the U.S. Geological Survey. Open-File Rep.-U.S. Geol. Surv., 76-844.

Heezen, B.C., and Ewing, M., 1952. Turbidity currents and submarine slumps and the 1929 Grand Banks earthquake. Am. J. Sci., 250:849-878.

Heezen, B.C., Hollister, C.D., and Ruddiman, W.F., 1966. Shaping of the continental rise by deep geostrophic contour currents. Science, 152:502508.

Imbrie, J., et al., 1988. Scientific goals of an Ocean Drilling Program designed to investigate changes in the global environment. In Munsch, G.B.(Ed.), Rep. Second Conf. Sci. Ocean Drilling, 15-46.

Kidwell, S.M., 1984. Outcrop features and origin of basin margin unconformities in the Lower Chesapeake Group (Miocene), Atlantic coastal plain AAPG Mem., 37:37-57.

May, J.A., Warme, J.E., and Slater, R.A., 1983. Role of submarine canyons on shelfbreak erosion and sedimentation: modern and ancient examples. In Stanley, D.J., and Moore, G.T. (Eds.), The Shelfbreak: Critical Interface on Continental Margins. Spec. Publ.-Soc. Econ. Paleontol. Mineral., $33: 315-332$

*Abbreviations for names of organizations and publications in ODP reference lists follow the style given in Chemical Abstracts Service Source Index (published by American Chemical Society).
McHugh, C.M., Ryan, W.B.F., and Schreiber, B.C., 1993. The role of diagenesis in exfoliation of submarine canyons. AAPG Bull., 77:145-172.

McMaster, R.L., Locker, S.D., and Laine, E.P., 1989. The early Neogene continental rise off the eastern United States. Mar. Geol., 87:137-163.

Miller, K.G., et al., 1994. Proc. ODP, Init. Repts., 150X: College Station, TX (Ocean Drilling Program)

Miller, K.G., Fairbanks, R.G., and Mountain, G.S., 1987. Tertiary oxygen isotope synthesis, sea-level history, and continental margin erosion. Paleoceanography, 2:1-19.

Miller, K.G., Kent, D.V., Brower, A.N., Bybell, L.M., Feigenson, M.D., Olsson, R.K., and Poore, R.Z., 1990. Eocene-Oligocene sea-level changes on the New Jersey coastal plain linked to the deep-sea record. Geol. Soc. Am. Bull., 102:331-339.

Miller, K.G., Mountain, G.S., and Tucholke, B.E., 1985. Oligocene glacio-eustacy and erosion on the margins of the North Atlantic. Geology, 13:10-13.

Miller, K.G., Wright, J.D., and Fairbanks, R.G., 1991. Unlocking the Ice House: Oligocene-Miocene oxygen isotopes, eustasy, and margin erosion. J. Geophys. Res., 96:6829-6848.

Mountain, G.S., and Tucholke, B.E., 1985. Mesozoic and Cenozoic geology of the U.S. Atlantic continental slope and rise. In Poag, C.W. (Ed.), Geologic Evolution of the United States Atlantic Margin: New York (Van Nostrand Reinhold), 293-341.

Olsson, R.K., Melillo, A.J., and Schreiber, B.L., 1987. Miocene sea level events in the Maryland coastal plain and the offshore Baltimore Canyon trough. In Ross, C., and Haman, D. (Eds.), Timing and Depositional History of Eustatic Sequences: Constraints on Seismic Stratigraphy. Spec. Publ. Cushman Found. Foraminiferal Res., 24:85-97.

Olsson, R.K., and Wise, S.W., 1987. Upper Paleocene to middle Eocene depositional sequences and hiatuses in the New Jersey Atlantic Margin. In Ross, C., and Haman, D. (Eds.), Timing and Depositional History of Eustatic Sequences: Constraints on Seismic Stratigraphy. Spec. Publ. Cushman Found. Foraminiferal Res., 24:99-112.

Owens, J.P., and Gohn, G.S., 1985. Depositional history of the Cretaceous series in the U.S. coastal plain: stratigraphy, paleoenvironments, and tectonic controls of sedimentation. In Poag, C.W. (Ed.), Geologic Evolution of the United States Atlantic Margin: New York (Van Nostrand Reinhold), $25-86$.

Paull, C.K., and Dillon, W.P., 1980. Erosional origin of the Blake Escarpment: an alternative hypothesis. Geology, 8:538-542.

Pisias, N.G., Shackleton, N.J., and Hall, M.A., 1985. Stable isotope and calcium carbonate records from hydraulic piston cored Hole 574A: high-resolution records from the middle Miocene. In Mayer, L., Theyer, F., Thomas, E., et al., Init. Repts. DSDP, 85: Washington (U.S. Govt. Printing Office), 735748 .

Poag, C.W., 1978. Stratigraphy of the Atlantic continental shelf and slope of the United States. Annu. Rev. Earth Planet. Sci., 6:251-280.

, 1980. Foraminiferal stratigraphy, paleoenvironments, and depositional cycles in the outer Baltimore Canyon Trough. In Scholle, P.A. (Ed.), Geological Studies of the COST No. B-3 Well, United States Mid-Atlantic Continental Slope Area. Geol. Surv. Circ. (U.S.), 833:44-65.

1985. Depositional history and stratigraphic reference section for central Baltimore Canyon trough. In Poag, C.W. (Ed.), Geologic Evolution of the United States Atlantic Margin: New York (Van Nostrand Reinhold), 217-263.

Poag, C.W., and Mountain, G.S., 1987. Late Cretaceous and Cenozoic evolution of the New Jersey continental slope and upper rise: an integration of borehole data with seismic reflection profiles. In Poag, C.W., Watts, A.B., et al., Init. Repts. DSDP, 95: Washington (U.S. Govt. Printing Office), 673-724.

Poag, C.W., and Sevon, W.D., 1989. A record of Appalachian denudation in postrift Mesozoic and Cenozoic sedimentary deposits of the U.S. middle Atlantic margin. Geomorphology, 2:119-157.

Poag, C.W., Watts, A.B., et al., 1987. Init. Repts. DSDP, 95: Washington (U.S. Govt. Printing Office).

Poore, R.Z., and Bybell, L., 1988. Eocene to Miocene biostratigraphy of New Jersey core ACGS\#4: implications for regional stratigraphy. U.S. Geol. Surv. Bull., 1829:1-22.

Posamentier, H.W., Jervey, M.T., and Vail, P.R., 1988. Eustatic controls on clastic deposition, I-Conceptual framework. Spec. Publ-Soc. Econ. Paleontol. Mineral., 42:109-124.

Reynolds, D.J., Steckler, M.S., and Coakley, B.J., 1991. The role of the sediment load in sequence stratigraphy: the influence of flexural isostasy and compaction. J. Geophys. Res., 96:6931-6949. 
Robb, J.M., Hampson, J.C., Jr., and Twichell, D.C., 1981. Geomorphology and sediment stability of a segment of the U.S. continental slope off New Jersey. Science, 211:935-937.

Sea Level Working Group, 1992. JOIDES J., 18:28-36.

Shackleton, N.J., and Opdyke, N.D., 1973. Oxygen isotope and paleomagnetic stratigraphy of equatorial Pacific core V28-238: oxygen isotope temperatures and ice volumes on a $10^{5}$ year and $10^{6}$ year scale. Quat. Res., 3:39-55.

, 1976. Oxygen-isotope and paleomagnetic stratigraphy of Pacific

Core V28-239: late Pliocene to latest Pleistocene. In Cline, R.M., and Hays, J.D. (Eds.), Investigations of Late Quaternary Paleoceanography and Paleoclimatology. Mem.-Geol. Soc. Am., 145:449-464.

Shepard, F.P., and Dill, R.F., 1966. Submarine Canyons and Other Sea Valleys: Chicago (Rand McNally).

Steckler, M.S., and Watts, A.B., 1982. Subsidence history and tectonic evolution of Atlantic-type continental margins. In Scrutton, R.A. (Ed.), Dynamics of Passive Margins. AGU Geodyn. Ser., 6:184-196.

Sugarman, P.J., Miller, K.G., Owens, J.P., and Feigenson, M.D., 1993. Strontium isotope and sequence stratigraphy of the Miocene Kirkwood Formation, Southern New Jersey. Geol. Soc. Am. Bull., 105:423-436.

Tucholke, B.E., 1981. Geological significance of seismic reflectors in the deep western North Atlantic basin. In Warme, J.E., Douglas, R.G., and Winterer, E.L. (Eds.), The Deep Sea Drilling Project: A Decade of Progress. Spec. Publ.-Soc. Econ. Paleontol. Mineral., 32:23-37.

Tucholke, B.E., and Mountain, G.S., 1979. Seismic stratigraphy, lithostratigraphy, and paleosedimentation patterns in the North American basin. In
Talwani, M., Hay, W., and Ryan, W. (Eds.), Deep Drilling Results in the Atlantic Ocean: Continental Margins and Paleoenvironment. Am. Geophys. Union, Maurice Ewing Ser., 3:58-86.

Vail, P.R., 1987. Seismic stratigraphy interpretation using sequence stratigraphy. Part 1: Seismic stratigraphy interpretation procedure. In Bally, A.W. (Ed.), Atlas of Seismic Stratigraphy (Vol. 1). AAPG Stud. Geol., 27:1-10.

Vail, P.R., Mitchum, R.M., Jr., Todd, R.G., Widmier, J.M., Thompson, S., III Sangree, J.B., Bubb, J.N., and Hatlelid, W.G., 1977. Seismic stratigraphy and global changes in sea level. In Payton, C.E. (Ed.), Seismic Stratigraphy-Applications to Hydrocarbon Exploration. AAPG Mem., 26:49-221.

van Hinte, J.A., Wise, S.W., Jr., et al., 1987. Init. Repts. DSDP, 93: Washington (U.S. Govt. Printing Office).

van Wagoner, J.C., Mitchum, R.M., Jr., Posamentier, H.W., and Vail, P.R., 1987. Key definitions of sequence stratigraphy. In Bally, A.W. (Ed.), Atlas of Seismic Stratigraphy. AAPG Stud. Geol., 27:11-14.

Watkins, J.S., and Mountain, G.S. (Eds.), 1990. Role of ODP Drilling in the Investigation of Global Changes in Sea Level. Rep. JOI/USSAC Workshop, El Paso, TX, Oct. 24-26, 1988.

Wright, J.D., and Miller, K.G., 1992. Miocene stable isotope stratigraphy, Site 747, Kerguelen Plateau. In Wise, S.W., Jr., Schlich, R., et al., Proc. ODP, Sci. Results, 120: College Station, TX (Ocean Drilling Program), 855-866. 